\title{
Palmitic Acid Curcumin Ester Facilitates Protection of Neuroblastoma against Oligomeric $\mathbf{A} \boldsymbol{\beta}_{40}$ Insult
}

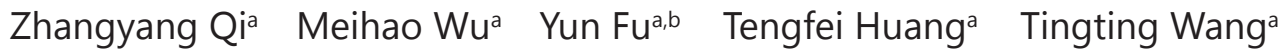 \\ Yanjie Sun ${ }^{\mathrm{a}}$ Zhibo Feng ${ }^{c}$ Changzheng Lia

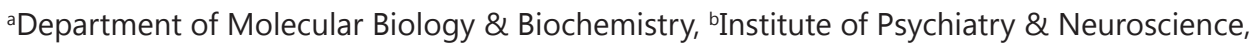 \\ 'Department of Anatomy, Xinxiang Medical University, Xinxiang, P. R. China
}

\section{Key Words}

Curcumin derivatives $\cdot$ ROS scavenger - Interaction - Liposome - Amyloid beta Spectral titration

\begin{abstract}
Background/Aims: The generation of reactive oxygen species (ROS) caused by amyloid- $\beta$ (A $\beta$ ) is considered to be one of mechanisms underlying the development of Alzheimer's disease. Curcumin can attenuate $A \beta$-induced neurotoxicity through ROS scavenging, but the protective effect of intracellular curcumin on neurocyte membranes against extracellular $A \beta$ may be compromised. To address this issue, we synthesized a palmitic acid curcumin ester (P-curcumin) which can be cultivated on the cell membrane and investigated the neuroprotective effect of P-curcumin and its interaction with A $\beta$. Methods: P-curcumin was prepared through chemical synthesis. Its structure was determined via nuclear magnetic resonance (NMR) and highresolution mass spectrometry (HRMS). An MTT assay was used to assess A $\beta$ cytotoxicity and the protective effect of $\mathrm{P}$-curcumin on SH-SY5Y cells. The effect of $\mathrm{P}$-curcumin on A $\beta$-induced ROS production in vitro and in vivo were assessed based on changes in dichlorofluorescein (DCF) fluorescence. A spectrophotometric method was employed to detect lipid peroxidation. To mimic the interaction of $\mathrm{P}$-curcumin on cell membranes with $A \beta$, liposomes were prepared by thin film method. Finally, the interactions between free P-curcumin and P-curcumin cultivated on liposomes and $A \beta$ were determined via spectrophotometry. Results: $A$ novel derivative, palmitic acid curcumin ester was prepared and characterized. This curcumin, cultivated on the membranes of neurocytes, may prevent $A \beta$-mediated ROS production and may inhibit the direct interaction between $A \beta$ and the cellular membrane. Furthermore, $P$-curcumin could scavenge $A \beta$-mediated ROS as curcumin in vitro and in vivo, and had the potential to prevent lipid peroxidation. Morphological analyses showed that $\mathrm{P}$-curcumin was better than curcumin at protecting cell shape. To examine P-curcumin's ability to attenuate direct interaction between $A \beta$ and cell membranes, the binding affinity of $A \beta$ to curcumin and P-curcumin was determined. The association constants for free P-curcumin and curcumin were $7.66 \times 10^{4}$
\end{abstract}

Z.-Y. Qi and M.-H. Wu contributed equally to this work.

Zhibo Feng

and Changzheng $\mathrm{Li}$
Department of Molecular Biology \& Biochemistry, Institute of Psychiatry \&

Neuroscience, Department of Anatomy, Xinxiang Medical University, Xinxiang,

(P. R. China); E-Mail zhdf2002@163.com, changzhengli@xxmu.edu.cn 
Qi et al.: Neuroblastoma Protection of Palmitic Acid Curcumin Ester

$\mathrm{M}^{-1}$ and $7.61 \times 10^{5} \mathrm{M}^{-1}$, respectively. In the liposome-trapped state, the association constants were $3.71 \times 10^{5} \mathrm{M}^{-1}$ for P-curcumin and $1.44 \times 10^{6} \mathrm{M}^{-1}$ for curcumin. With this data, the thermodynamic constants of $\mathrm{P}$-curcumin association with soluble $A \beta(\Delta H, \Delta S$, and $\Delta G)$ were also determined. Conclusion: Cultivated curcumin weakened the direct interaction between $A \beta$ and cell membranes and showed greater neuroprotective effects against $A \beta$ insult than free curcumin.

(C) 2017 The Author(s)

Published by S. Karger AG, Basel

\section{Introduction}

Alzheimer's disease (AD) is a devastating neurodegenerative disease and is the primary cause of cognitive impairment worldwide; elderly individuals are at the highest risk for developing the disease [1]. Multiple factors have been suggested to contribute to the development of $A D$, among which amyloid- $\beta(A \beta)$ and oxidative stress have been well investigated $[2,3]$. Recently emerged evidence indicates that the abnormal misfolding and aggregation of $A \beta$ peptides into $\beta$-sheet-enriched fibrillar aggregates are involved in the initial neurodegeneration found in AD [4], which disrupts neuronal synaptic plasticity and results in early cognitive impairment $[5,6]$. $A \beta$, a peptide composed of 39-42 amino acids, is usually produced in all neurons through sequential proteolytic processing of a membraneattached amyloid precursor protein (APP) [7-9]. Although multiple assemblies of A $\beta$ exist, $A \beta$ oligomers play a central role in the start of $A D[10,11]$. Therefore, $A \beta$ oligomerization inhibitors have been proposed as novel therapeutic agents for the treatment of AD [6, 12-14]. The mechanism by which $A \beta$ exerts cellular toxicity has been extensively studied. Some details, such as oxidative stress and $A \beta$ interaction with the cell membrane leading to dysfunction of nerve cells, are well-accepted concepts in senile degenerative disease [15]. Increased oxidative damage by reactive oxygen species (ROS) and reactive nitrogen species is consistently found in the brains of patients with AD [16]; biometals, mitochondrial dysfunction, and $A \beta$ are the main contributors [17]. $A \beta$ generates ROS through Fenton-like reactions in the presence of metal ions, as has been proven through in vitro assays [18]. The toxic properties of $A \beta$ are mediated by several mechanisms, such as oxidative stress, mitochondrial diffusion, alterations in membrane permeability, inflammation, synaptic dysfunction, and excitotoxicity, and through interaction with neurotransmitter receptors [19-22].

Preclinical studies have shown that antioxidant therapy for AD has achieved general success [23]. The intake of curcumin, the main active ingredient in the spice turmeric, has been suggested to account for the lower incidence and prevalence of $\mathrm{AD}$ in the East Asian population $[24,25]$. Studies have shown that curcumin has diverse biological properties, including antioxidant, anti-inflammatory, and anti-cancer properties [26-28]. The neuroprotective effect of curcumin that improves the pathology of AD is believed to be partly due to its anti-oxidative and anti-inflammatory properties [29]. In addition, numerous studies have been conducted to determine how curcumin directly affects the $A \beta$ aggregation process; unfortunately, inconsistent and sometimes contradictory findings have been reported [30-32]. Therefore, the interaction of curcumin with $A \beta$ remains to be elucidated. While generally directly disrupting $A \beta$ aggregation, curcumin is involved in attenuating the toxicity of $A \beta$ through multiple pathways, such as the inhibition of oxidative damage and tau hyperphosphorylation [33, 34] and an increase in cellular phagocytosis of macrophages for the removal of $A \beta$ [35]. Curcumin has also been used for detecting $A \beta$ in the diagnosis of $A D$ due to its fluorescent characteristic $[36,37]$. However, to date, only a few studies regarding the effect of curcumin on neurocyte membranes have been conducted. As curcumin is now known to show excellent antioxidative activity, accumulated curcumin on cell membranes may be beneficial in protecting these membranes from oxidative damage and from direct $A \beta$ insult. To test this hypothesis, we attached palmitic acid to curcumin through an ester bond in order to investigate its protective effect on SH-SY5Y against A $\beta$ insult. Our results clearly showed that the modified curcumin could attenuate $A \beta$-induced cellular damage and had similar advantages to curcumin in neuroprotection. 


\section{Cellular Physiology Cell Physiol Biochem 2017;44:618-633 \begin{tabular}{l|l} 
and Biochemistry Published $\begin{array}{l}\text { DOI: 10.1159/000485117 } \\
\text { (c) } 2017 \text { The Author(s). Published by S. Karger AG, Basel } \\
\text { www.karger.com/cpb }\end{array}$
\end{tabular}}

Qi et al.: Neuroblastoma Protection of Palmitic Acid Curcumin Ester

\section{Materials and Methods}

\section{General Information}

MTT, curcumin, and other chemicals were purchased from Sigma-Aldrich (Sigma, Shanghai, China). Palmitic acid chloride and triethylamine were purchased from Saen Chemical Technology Co., Ltd. (Shanghai, China). 4-Dimethylaminopyridine (DMAP) was obtained from TCI Chemical Industry Development Co., Ltd (Shanghai, China). 1, 1,1, 3,3, 3-hexafluoro-2-propanol, 1, 2-Dimyristoyl-sn-glycero-3-phosphocholine (DMPC), and phosphatidylcholine were purchased from Aladdin (Aladdin Bio-chem Technology, Shanghai, China). Dulbecco's modified Eagle's medium (DMEM) was purchased from Solarbio (Solarbio Life Science, Beijing, China).

\section{Preparation of palmitic acid curcumin ester (P-curcumin)}

P-curcumin was produced via an esterification reaction. Curcumin (2 mmol) and triethylamine (3 mmol) were dissolved in ice-cold anhydrate dichloromethane for $20 \mathrm{~min}$ after which a trace amount of DMAP was added. Palmitic acid chloride $(2 \mathrm{mmol}$ ) in the same solvent was added dropwise over the course of $1 \mathrm{~h}$. The resulting solution was warmed to room temperature and allowed to react for $24 \mathrm{~h}$, Thin layer chromatography (TLC) was performed to trace the reaction process (chloroform/methanol = 20:1). The reaction mixture was subjected to flush column purification (chloroform/methanol = 20:1, 18:1, 14:1); the oily fractions were collected and dried in vacuum. ${ }^{1} \mathrm{HNMR}$ (Bruker, $\left.\mathrm{CDCl}_{3}\right): 7.65(\mathrm{~m}, 1 \mathrm{H}, \mathrm{J}=8 \mathrm{~Hz}), 7.60(\mathrm{~m}$, $1 \mathrm{H}, \mathrm{J}=8 \mathrm{~Hz}$ ), $7.16(\mathrm{~m}, 3 \mathrm{H}, \mathrm{J}=4 \mathrm{~Hz}), 7.07(\mathrm{~d}, 2 \mathrm{H}, \mathrm{J}=4 \mathrm{~Hz}), 6.96(\mathrm{~d}, 1 \mathrm{H}, \mathrm{J}=8 \mathrm{~Hz}), 6.60$ (d, 2H,J = $16 \mathrm{~Hz}), 6.50$ $(\mathrm{d}, 2 \mathrm{H}, \mathrm{J}=16 \mathrm{~Hz}), 5.87$ (d, 1H, J = 4Hz), $3.96\left(\mathrm{~s}, \mathrm{O}-\mathrm{CH}_{3}\right), 3.87$ (s, O-CH3), $2.61(\mathrm{q}, 2 \mathrm{H}, \mathrm{J}=8 \mathrm{~Hz}), 1.77(\mathrm{~m}, 2 \mathrm{H}$, $\mathrm{J}=8 \mathrm{~Hz}), 1.26$ (m, 26H, J = $8 \mathrm{~Hz}), 0.89$ (tri, 3H, J = $8 \mathrm{~Hz}) \cdot{ }^{13} \mathrm{CNMR}(\mathrm{ppm}): 184.38,181.90,171.74,151.44$, 148.05, 146.86, 141.36, 141.12, 139.48, 133.96, 132.62, 129.12, 127, 55, 124.16, 123.29, 123.03, 122.16, $121.75,120.98,114.89,111.42,109.70,101.54,55.91,34.57,34.06,31.94,29.71,29.68,29.64,29.53,29.38$, 29.30, 29.07, 24.97, 22.71, 14.15. ESI-MS (microTOF-Q III, Bruker): m/z: $\mathrm{C}_{37} \mathrm{H}_{50} \mathrm{O}_{7}: 629.3447$ (M+Na, calcd: $629.3454)$.

\section{Preparation of $A \beta$ aggregates}

Lyophilized $A \beta_{40}$ (1.5 mg; Peptide Institute, Shanghai) was placed in siliconized Eppendorf tubes (1.5 $\mathrm{ml}$ ) and dissolved in $600 \mu \mathrm{L}$ of cold 1, 1,1, 3,3, 3-hexafluoro-2-propanol (HFIP), a hydrogen-bond breaker used to eliminate pre-existing structural in homogeneities in $A \beta$ [38]. This solution was incubated for 10 min until it became clear. Then, $340 \mu \mathrm{L}$ of deionized water was added and incubated for 20 min. Finally, the mixture was centrifuged at $10000 \mathrm{rpm}$ for $10 \mathrm{~min}$. The supernatant was transferred to a new tube and blow dried with $\mathrm{N}_{2}(10 \mathrm{~min})$. The resulting peptide was stored as a film at $-20^{\circ} \mathrm{C}$. Before use, the HFIP-pre-treated $A \beta$ was resuspended in dimethyl sulfoxide (DMSO) and sonicated for $15 \mathrm{~min}$. In order to prepare oligomer $A \beta_{40}$, the above $A \beta_{40}$ solution was rocked on a shaker (500 rpm) for $24 \mathrm{~h}$, as described previously [39]. The resulting oligomer $A \beta_{40}$ solution was stored at $4{ }^{\circ} \mathrm{C}$ and used within 7 days for cell viability and other assays. Curcumin and P-curcumin used in the present study were dissolved in $10 \mathrm{mM}$ DMSO. The experimental procedures were performed in the dark to avoid light exposure.

\section{Cell viability (MTT assay)}

SH-SY5Y cells were plated at a density of $1 \times 10^{4}$ cells/well into 96-well plates and incubated for $12 \mathrm{~h}$ at $37^{\circ} \mathrm{C}$. Following the removal of cell culture, varying amounts of P-curcumin were added in DMEM without FBS and incubated in a humidified atmosphere of $5 \% \mathrm{CO}_{2}$ for $24 \mathrm{~h}$. Then, $10 \mu \mathrm{L}$ of MTT solution (5 mg/mL) was added to each well and incubated for $4 \mathrm{~h}$. The cell culture was removed and $100 \mu \mathrm{L}$ of DMSO was added to each well to dissolve the formazan crystals. The measurement of absorptions of the solutions, which were related to the number of live cells, was performed on a microplate reader (MK3, Thermo Scientific) at 570 nm. Percent growth inhibition was defined as percent absorbance inhibition within appropriate absorbance in each cell line. The same assay was performed in triplets.

For the assay of the protective effect of P-curcumin against A $\beta$ toxicity, a similar protocol was used as described above, but with slight modifications. The cells seeded in the well plate were grown in DMEM with FBS for $24 \mathrm{~h}$. After removal of the cell culture, the cells were pretreated with P-curcumin $(0.2 \mu \mathrm{M})$ for $4 \mathrm{~h}$ and then incubated with $10 \mu \mathrm{M} \mathrm{A} \beta_{40}$ for $24 \mathrm{~h}$. Finally, MTT was added as mentioned above to perform the assay. 


\section{Cellular Physiology Cell Physiol Biochem 2017;44:618-633 \begin{tabular}{l|l|l|} 
DOI: 10.1159/000485117 & O 2017 The Author(s). Published by S. Karger AG, Basel \\
www.karger.com/cpb
\end{tabular} \\ Qi et al.: Neuroblastoma Protection of Palmitic Acid Curcumin Ester}

Morphological studies were conducted using an inverted microscope (Zeiss, vert A1, Shanghai Batuo Instrument Co., Ltd, Shanghai, China). The images of SH-SY5Y cells exposed to P-curcumin $(2.5$ or $5.0 \mu \mathrm{M}$ P-curcumin or P-curcumin-Cu) for $16 \mathrm{~h}$ or $48 \mathrm{~h}$ were recorded (objective size: $10 \times 20$ ).

\section{ROS detection in vitro and in vivo}

The assessment of ROS production was conducted as previously reported [40]. In brief, $\mathrm{H}_{2}$ DCF-DA was first converted to dichlorofluorescein (DCF) by $\mathrm{NaOH}$; the neutralized hydrolysate was used for the in vitro assay. The reaction system contained a single reagent or multicomponents in $50 \mathrm{mM}$ sodium phosphate buffer (pH 7.4) with a total volume of $1 \mathrm{~mL}$, i.e., $0.4 \mu \mathrm{M} \mathrm{DCF}$, or with $2 \mu \mathrm{M}\left(\mathrm{NH}_{4}\right)_{2} \mathrm{Fe}\left(\mathrm{SO}_{4}\right)_{2}\left(\right.$ or CuCl $_{2}, \mathrm{P}$-curcumin, curcumin, and $\mathrm{A} \beta_{40}$ ) and $20 \mu \mathrm{M} \mathrm{H}_{2} \mathrm{O}_{2}$ for the Fenton reactions. Fluorescence was detected using an FC-960 spectrofluorometer (excitation at 488 and emission at $525 \mathrm{~nm}$ ) over $4.5 \mathrm{~min}$ at room temperature.

The intracellular ROS assay was measured as recommended by the company (Beyotime Biotechnology, Beijing, China). Approximately $10^{6}$ SH-SY5Y cells were used in the assay. Following washing with PBS, the cell pellets were re-suspended in $\mathrm{H}_{2}$ DCF-DA containing serum-free culture medium and incubated for 30 min. Next, the stained cells were washed with serum-free culture medium. Then, $100 \mu \mathrm{L}$ of the cell culture was transferred to individual polymerase chain reaction (PCR) tubes and the test compound (or positive control) was added, followed by incubation for $5 \mathrm{~h}$. Next, $10 \mu \mathrm{M}$ oligomer $\mathrm{A} \beta_{40}$ (with or without copper chloride) was added and incubated for $24 \mathrm{~h}$. The cell suspension was used directly for ROS detection (excitation at $488 \mathrm{~nm}$ and emission at $525 \mathrm{~nm}$ ) using an FC-960 spectrofluorometer.

\section{Preparation of liposome trapped P-curcumin}

Liposomes were prepared via the thin film method with some modifications [41]. In brief, soya lecithin (200 mg) and cholesterol (20 mg) were dissolved in $5 \mathrm{ml}$ of chloroform and $10 \mathrm{mg}$ P-curcumin was added to the solution. The mixture was evaporated in a rotary evaporator at $50{ }^{\circ} \mathrm{C}$. The thin film that formed in the round-bottomed flask was hydrated with $5 \mathrm{ml}$ of $50 \mathrm{mM}$ phosphate buffer (pH 6.8) for $12 \mathrm{~h}$ and sonicated for $30 \mathrm{~min}$. A clear solution was obtained, which was stored at $4{ }^{\circ} \mathrm{C}$. The enhanced fluorescence (10-fold) of P-curcumin was also observed.

\section{Lipid peroxidation assay}

Lipid peroxidation analysis was performed based on spectrophotometry, in which the ferrous ion is oxidized by lipid hydroperoxides to the ferric ion and subsequently reacts with thiocyanate to form a colored complex [42]. Briefly, the trypsinized cells were collected and treated with the investigated drugs (or $\mathrm{A} \beta$ ) for $4 \mathrm{~h}$; the supernatant was removed by centrifugation and washed with PBS. The peroxidized lipid was extracted using deoxygenated $\mathrm{CHCl}_{3} / \mathrm{MeOH}(2: 1, \mathrm{v} / \mathrm{v}$ mixture, $1000 \mu \mathrm{L})$, and the lipids were transferred to a $5 \mathrm{~mL}$ volumetric flask, which contained $100 \mu \mathrm{L}$ of ferrous sulfate $(0.2 \mathrm{M} \mathrm{HCl})$ and $100 \mu \mathrm{L}$ of 3\% deoxygenated thiocyanate (methanol) for $60 \mathrm{~min}$. Finally, deoxygenated $\mathrm{CHCl}_{3} / \mathrm{MeOH}$ solvents were added to the given volume. The absorbances at $500 \mathrm{~nm}$ were measured using a UV-2450 spectrophotometer (Shimadzu Co. Ltd, Suzhou, China). The molar absorptivity of the ferric thiocyanate complex expressed per mol of $\mathrm{LOOH}$ was determined to be $58,440 \mathrm{M}^{-1} \mathrm{~cm}^{-1}$ [42].

\section{UV-vis spectrophotometric measurements}

The absorbance spectra of P-curcumin were recorded using a UV-2450 spectrophotometer (Shimadzu)

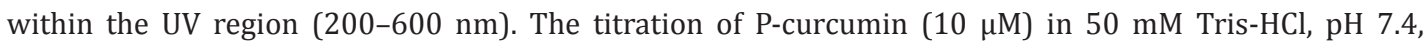
containing $10 \%$ methanol, was performed by the addition of various concentrations of $A \beta_{40}$ at $298 \mathrm{~K}$. For liposome titration, the spectra were obtained in normal saline.

\section{Fluorescence measurements}

For the fluorescence spectra, the excitation wavelength was set at $275 \mathrm{~nm}$ and the emission spectra were recorded in the 300-550 $\mathrm{nm}$ range. Both excitation and emission slit widths were adjusted to $5 \mathrm{~nm}$. In this assay, $4.0 \mathrm{~mL}$ of P-curcumin (or curcumin as control) solution at a fixed concentration of $10 \times 10^{-5} \mathrm{M}$ was accurately added into the quartz cell (1-cm path length) and manually titrated by successive additions of $1.0 \mathrm{mM} \mathrm{A} \beta$ at intervals of $5 \mathrm{~min}$. Fluorescence emission spectra were then obtained using an RF-5301 spectrofluorophotometer (Shimadzu Scientific Instruments, Kyoto, Japan) at three different temperatures $(298,306$, and $310 \mathrm{~K})$. 
Statistical analysis

Data were analyzed with Prism 5.0 (GraphPad Software Inc., San Diego, USA). Comparisons were made using Student's t-test. Results were presented as the mean \pm SD. $P<0.05$ was considered statistically significant.

\section{Results}

Antiproliferative activity of palmitic acid curcumin ester (P-curcumin)

$A \beta$ is toxic to neuron or nerve cells through ROS or direct interaction with the cell membrane [22], thus, ROS scavengers, such as curcumin, are potent protectants against $A \beta$ toxicity. To achieve an optimal effect, a ROS scavenger can be cultivated on neuron or nerve cell surfaces. To test this hypothesis, we chose palmitic acid as a root that stretches across the cell membrane and prepared the curcumin ester (P-curcumin) through chemical synthesis, as described in the experimental section. The structure of the ester was characterized by nuclear magnetic resonance (NMR) and mass spectrometry (MS) spectra (for all online suppl. material, see www.karger.com/doi/ 10.1159/000485117, Fig. S2-S4), as indicated in Fig. 1a. The spectral data showed that the compound had adequate purity $(>95 \%$, see online suppl. material, Fig. S1-S2). Next, we screened the preliminarily cytotoxicity of P-curcumin against SH-SY5Y human neuroblastoma cells. The resultant dose-response curves are depicted in Fig. 1b, where it can be seen that P-curcumin exhibited significant inhibition $(30 \%)$ in a concentration-independent manner, and that the half-maximal inhibition concentration $\left(\mathrm{IC}_{50}\right.$ ) of curcumin was $23.8 \mu \mathrm{M}$. Moreover, because P-curcumin was made from a combination of palmitic acid and curcumin with an ester bond and esterase is present in cells, in order to exclude the possibility that P-curcumin cytotoxicity due to either palmitic acid or curcumin, the effect of palmitic acid and P-curcumin on neuroblastoma cells was also investigated. As shown, see online suppl. material, in Fig. S5a, palmitic acid did not exhibit obvious cytotoxicity bellow $25 \mu \mathrm{M}$ and P-curcumin displayed a different cytotoxic profile, indicating that the P-curcumin was not hydrolyzed by esterase. Thus, the possibility that the cytotoxic effect of P-curcumin was from either reacting agent was excluded.

\section{Cultivation of P-curcumin on the cellular membrane}

Following the MTT assay, we examined the distribution of P-curcumin via cell staining (using curcumin as a control) based on its fluorescent features. As shown in Fig. 2b, P-curcumin accumulated on the cell surface, indicating that the long fatty chain was inserted into the cell membrane. However, curcumin did not exhibit this feature (Fig. 2e). To exclude the possibility that the palmitic acid affected the distribution of curcumin, the SH-SY5Y cells were synchronously treated with curcumin and palmitic acid. As shown, see online suppl. material, in Figs. S5b-c, the presence of palmitic acid did not alter the distribution of curcumin (see online suppl. material, Fig. S5b-c), indicating that only P-curcumin possessed



Fig. 1. The chemical structure of P-curcumin (P-cur) and its proliferation inhibition assay. (a) Structures of P-curcumin and curcumin (cur); (b) Growth inhibition curve of cur and P-cur against the SH-SY5Y human neuroblastoma cell line $(24 \mathrm{~h}) ; \mathrm{IC}_{50}=23.8 \pm 0.6 \mu \mathrm{M}$ for cur, P-cur had an almost constant inhibition at $\sim 30$ $\%$ at the investigated concentration. 


\section{Cellular Physiology and Biochemistry}

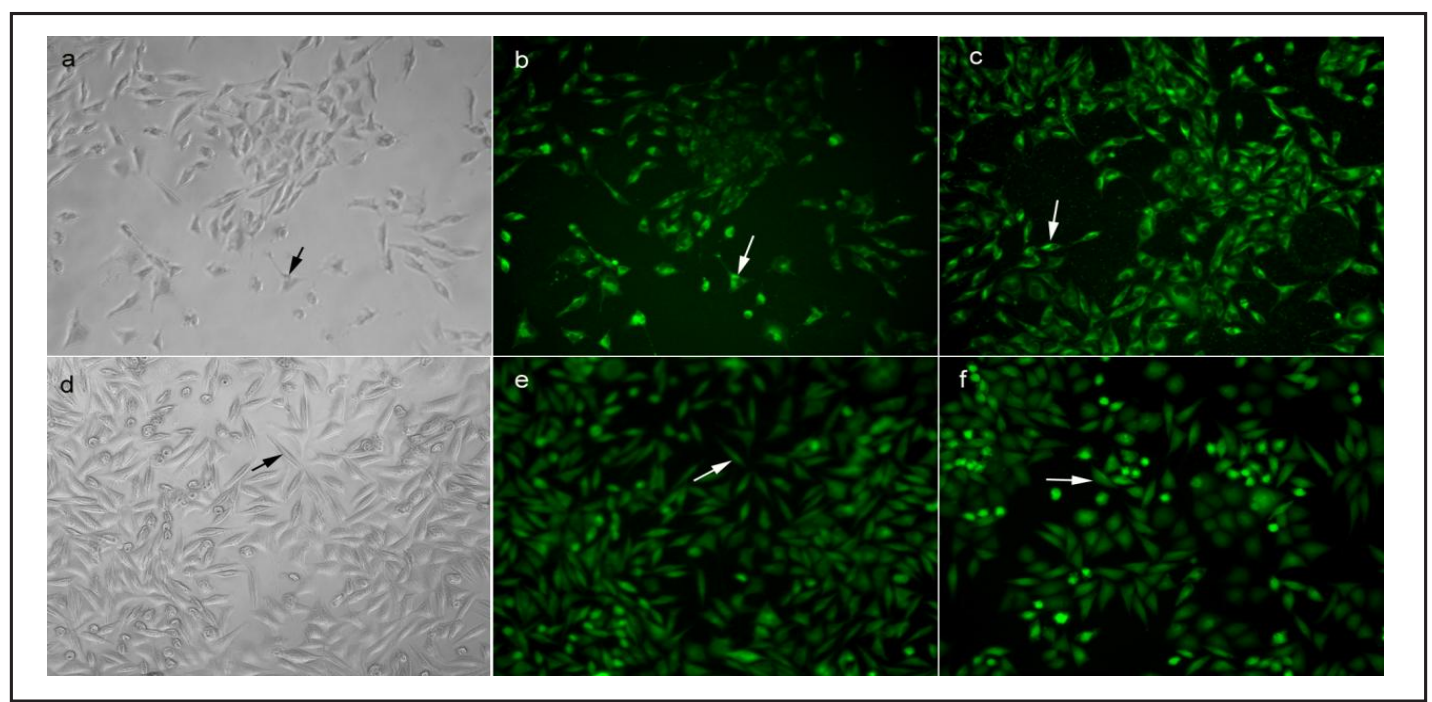

Fig. 2. SH-SY5Y human neuroblastoma cells stained with curcumin and P-curcumin. (a) White photo of (b); (b) P-curcumin accumulated on the cell surface (incubation for $30 \mathrm{~min}$ at $20 \mu \mathrm{M}$ ); (c) P-curcumin-stained cells after the addition of oligomeric $A \beta$; (d) white photo of (e); (e) curcumin-stained cells; (f) curcuminstained cells after addition of oligomeric $A \beta$. Arrows indicate the cell position or curcumin stained state.

this unique feature. Curcumin fluorescence intensity varied with an increase in $A \beta$ oligomer [37]. We questioned whether the "cultivated" curcumin had characteristics similar to those of curcumin; thus, we evaluated the effect of oligomer $A \beta$ (in the study, $A \beta$ represent $A \beta_{40}$, unless otherwise indicated) on cellular fluorescence. $A \beta$ oligomer has been identified as one of the main components in the brain of patients with $\mathrm{AD}$; therefore, we prepared the oligomer according to a method described in the literature [38]. As expected, there was a slight enhancement in the fluorescence upon addition of oligomeric $A \beta$ to the P-curcuminstained cells (Fig. 2c), indicating that the interaction of $A \beta$ with cultivated curcumin was similar to that with free curcumin (Fig. 2f).

\section{Protective effect of P-curcumin on SH-SY5Y cells exposed to A $\beta$}

As mentioned above, oligomer $A \beta$ is one of the toxic peptide oligomers, and it has been well documented that curcumin attenuates the toxicity of oligomer $A \beta$ by inhibiting the aggregation of $A \beta$ or ROS scavenging $[42,43]$. Therefore, we evaluated if P-curcumin had a similar protective effect as curcumin. We preloaded p-curcumin on the cell surface before addition of $10 \mu \mathrm{M} \mathrm{A} \beta$. As shown in Fig. 3a, P-curcumin attenuated the cytotoxicity of $A \beta$ similar to curcumin, indicating that the modification did not significantly change the attenuation of cytotoxicity caused by soluble $A \beta$ (Fig. 3a). Copper ion is another contributor to $\mathrm{AD}$ pathology and acts concomitantly with $A \beta$. Thus, the protective effect of the agents on $A \beta$ in the presence of copper ions was also investigated. Both curcumin and P-curcumin exhibited some degree of protective effect, as indicated in Fig. 3a. To further assess the protective effect of $\mathrm{P}$-curcumin against fibrillar $\mathrm{A} \beta$, a similar protocol was applied and similar results were obtained as with soluble $A \beta$. However, P-curcumin exhibited a marginally enhanced protective effect compared with curcumin (Fig. 3b).

\section{Protective effect of P-curcumin on SH-SY5Y cell morphology}

To determine whether P-curcumin affects cellular morphology, the changes in morphology after exposure to P-curcumin were recorded; as a control, curcumin-treated cells were included in microscopic analyses. As shown in Fig. 4, P-curcumin exhibited a weaker effect on cell morphology than curcumin (Figs. $4 \mathrm{~b}-\mathrm{c}$ ). To further determine the protective effect against oligomeric $A \beta$ insult, the effect of $A \beta$ on SH-SY5Y cells was assessed. Fig. $4 d$ clearly showed cytotoxicity caused by $A \beta$, which caused the cells to be round. However, in the 


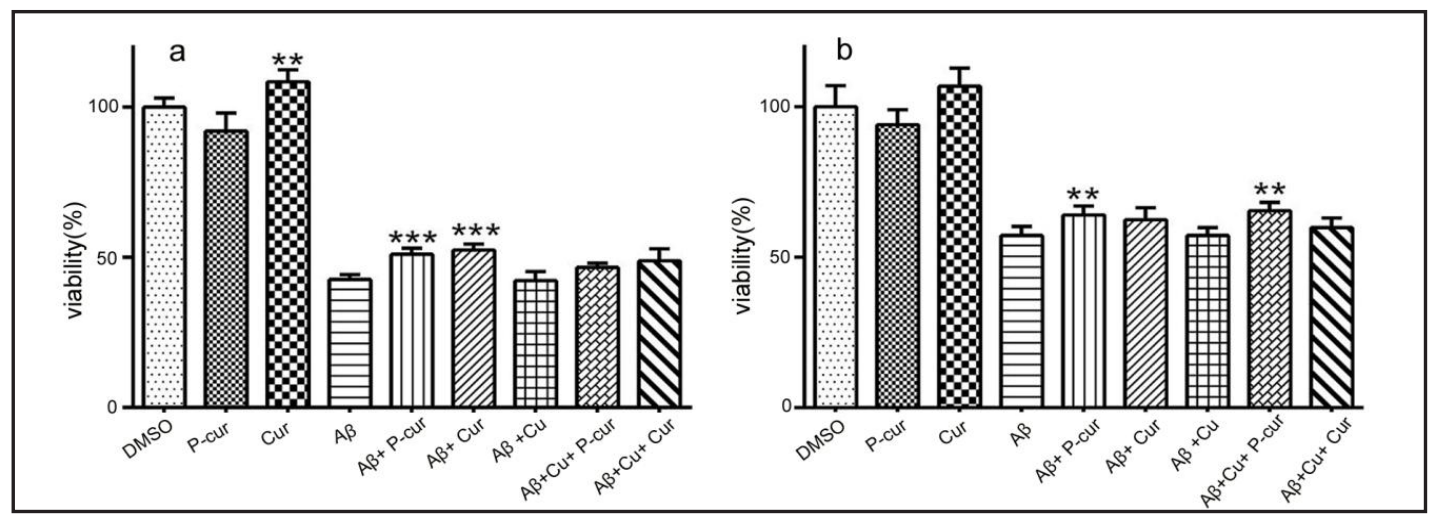

Fig. 3. Protective effect of P-curcumin against oligomer $A \beta(a)$ and fibrillar $A \beta$ (b). The effect of copper ions involved Fenton-like reactions; $\mathrm{Cu}=\mathrm{Cu}^{2+}$. Data were collected from two independent experiments. ${ }^{* *} \mathrm{p}<0.05$ and ${ }^{* * *} \mathrm{p}<0.01$ indicate significant differences between control (dimethyl sulfoxide or $\mathrm{A} \beta$ or $\mathrm{A} \beta^{+} \mathrm{Cu}$ ) and the P-curcumin treated group.



Fig. 4. Morphological analyses of SH SY5Y human neuroblastoma cells after exposure to the investigated agents. (a) Control; (b) P-curcumin $(10 \mu \mathrm{M})$ treated for $20 \mathrm{~h}$; (c) curcumin $(10 \mu \mathrm{M})$ treated for $20 \mathrm{~h}$; (d) A $\beta$ $(10 \mu \mathrm{M})$ treated for $20 \mathrm{~h}$; (e) $\mathrm{A} \beta$ and P-curcumin $(10 \mu \mathrm{M})$ treated for $20 \mathrm{~h}$; (f) $\mathrm{A} \beta$ and curcumin treated for $20 \mathrm{~h}$. The arrows indicated the morphology after being treated with P-curcumin or curcumin.

presence of P-curcumin, the cellular morphology did not significantly change, whereas in the presence of curcumin, the cells were partly round (Figs. 4e-f).

\section{ROS scavenging ability of P-curcumin in vitro and in vivo}

Many studies have shown that curcumin scavenges ROS, thereby protecting the host cell, and led to a question of whether the modification of curcumin to P-curcumin would change this antioxidant feature. P-curcumin also has potent metal chelating ability, which may involve Fenton-like reactions. Therefore, the ROS generation and scavenging ability of P-curcumin in different conditions were assessed. The addition of P-curcumin (or curcumin) to a Fenton reaction in vitro led to a decrease in ROS (Fig. 5a), indicating that P-curcumin (or curcumin) acts as an ROS scavenger or that P-curcumin-Fe ${ }^{2+}$ was not redox active. In the presence of ferrous ions, $A \beta$ has a strong ROS-generating ability [44], but the introduction of P-curcumin (or curcumin) caused a significant decrease in ROS (Fig. 5a), which indicated that P-curcumin (or curcumin) can counteract A $\beta$-mediated ROS. Similarly, A $\beta$ in the presence of copper ions can induce massive ROS (Fig. 5 b), and P-curcumin (or curcumin) efficiently decreased the ROS levels. Interestingly, $A \beta$ induced decomposition of hydrogen peroxide 

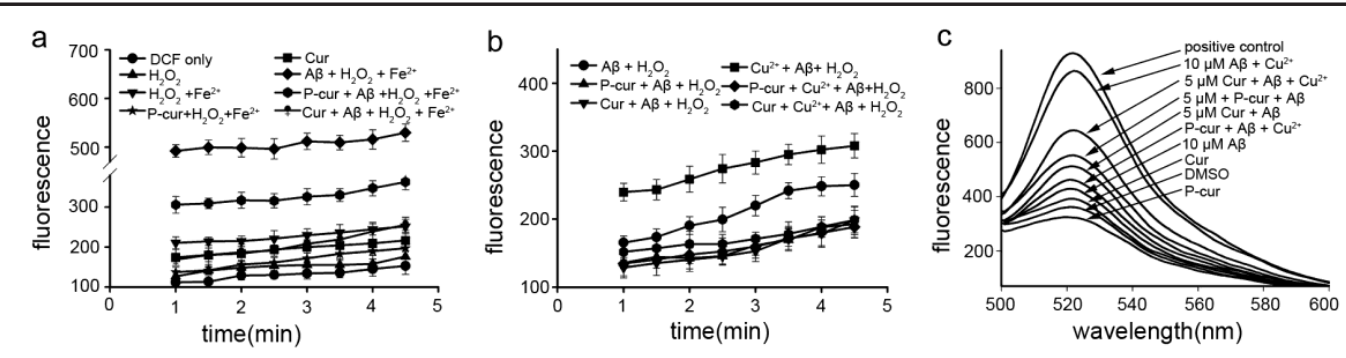

Fig. 5. ROS scavenging ability of P-curcumin (P-cur) and curcumin (Cur) in vitro and in vivo. (a) The effect of P-cur (or Cur) on A $\beta$-involved Fenton-like reactions; (b) the effect of P-cur (or Cur) on A $\beta$-involved ROS generation in the presence of copper ions; (c) ROS scavenging ability of P-cur (or Cur) in vivo.

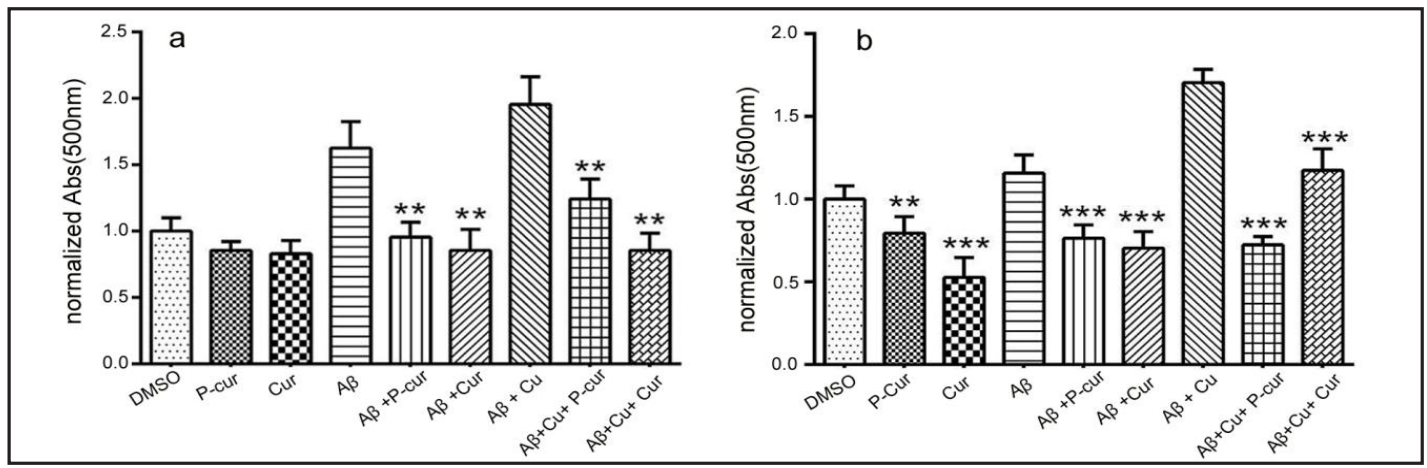

Fig. 6. Protective effect of P-curcumin and curcumin on cellular lipid peroxidation in the presence of soluble $A \beta(a)$ and fibrillar $A \beta$ (b) insults. The absorbance at $500 \mathrm{~nm}$ was normalized using dimethyl sulfoxide (DMSO) as a control. The average values of two independent experiments were considered. ${ }^{* *} \mathrm{p}<0.05$ and ${ }^{* * *} \mathrm{p}<0.01$ indicate significant differences between the control (DMSO or $\mathrm{A} \beta$ or $\mathrm{A} \beta+\mathrm{Cu}$ ) and the agent treated group.

(Fig. 5b) to produce ROS, and P-curcumin (curcumin) reduced the levels of ROS. An in vivo ROS assay confirmed that P-curcumin and curcumin can act as ROS scavengers in the abovementioned conditions, indicating that the modification of curcumin did not alter its behavior (Fig. 5c).

\section{Lipid peroxidation in the presence of P-curcumin during ROS stimulation}

$\mathrm{AD}$ pathology is correlated to ROS-induced oxidative stress. The source of ROS originates from intracellular and extracellular ROS. A $\beta$ in the presence of metal ions, such iron or copper ions, was involved in Fenton-like reactions [22], and oligomeric or fibrillar A $\beta$-mediated ROS production was extracellular, which may directly contribute to lipid peroxidation. Therefore, the cultivated curcumin may efficiently protect lipids from peroxidation. To test this hypothesis, a lipid peroxidation assay was performed [41]. As shown in Fig. 6a, in the presence of soluble $A \beta$, P-curcumin, similar to curcumin, significantly reduced lipid peroxidation. The protective effect of P-curcumin was less than that of curcumin, which may be due to the presence of fewer phenol groups in P-curcumin. Similar protective effects against peroxidation caused by fibrillar $A \beta$ were observed, but the difference was that the protective effect of P-curcumin was superior to that of curcumin in the presence of copper ions and $A \beta$ mediated membrane peroxidation (Fig. $6 b$ ).

Investigation into the interaction of P-curcumin and liposome-trapped P-curcumin with $A \beta$ via $U V$-vis spectrometry

As mentioned above, we hypothesized that $\mathrm{P}$-curcumin may isolate the direct interaction of oligomeric or fibrillar $A \beta$ with the cell membrane, which may decrease the risk of 

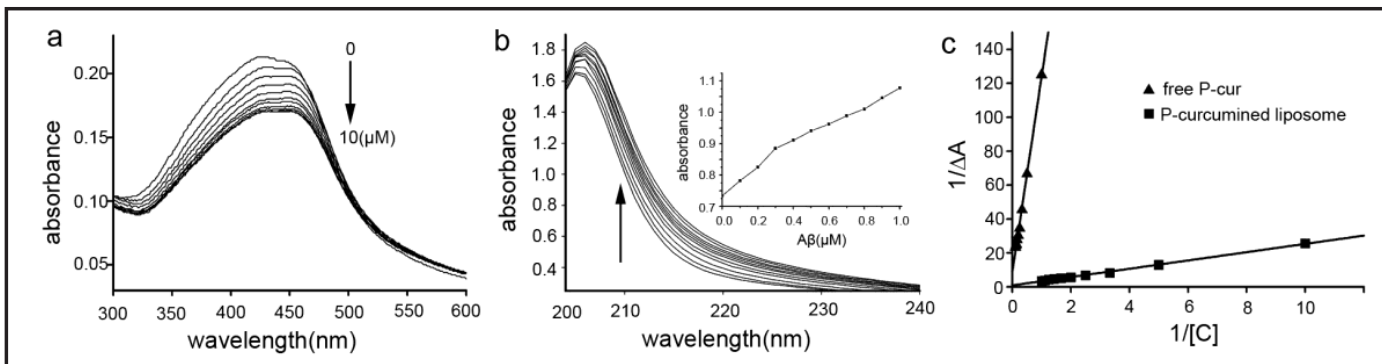

Fig. 7. Interaction of P-curcumin and liposome trapped P-curcumin with $A \beta$ : (a) Spectral changes of P-curcumin upon addition of $A \beta$; (b) Spectral changes of liposome trapped P-curcumin upon addition of $A \beta$; the insert indicates the absorbance increase with $\mathrm{A} \beta$; (c) Linear plots for $1 / \Delta A_{\text {abs }}$ versus $1 /[\mathrm{A} \beta]$ at $288 \mathrm{~K}$.

exogenous $A \beta$ affecting neurocyte function. Therefore, we examined the binding affinity to analyze the interaction between $A \beta$ and P-curcumin. Using UV-vis spectrometry, we observed that free P-curcumin interacted with oligomeric $A \beta$. As shown in Fig. 7a, the absorbance of $P$-curcumin decreased upon the addition of $A \beta$, thereby indicating an interaction between them. To quantitatively analyze this interaction, the Benesi-Hildebrand equation was used to determine the interaction-related thermodynamic parameter [45]:

$$
1 / \Delta \mathrm{A}_{\mathrm{abs}}=(1 /[\mathrm{S}][\mathrm{L}] \Delta \epsilon \mathrm{K})+(1 /[\mathrm{S}] \Delta \epsilon)(1)
$$

where $\Delta \mathrm{A}_{\mathrm{abs}}$ is the change in the absorbance at $413 \mathrm{~nm}, \mathrm{~K}$ is the binding constant, [S] is the concentration of P-curcumin, [L] is the concentration of $A \beta$, and $\Delta \varepsilon$ (or $\Delta \varepsilon=\varepsilon_{\text {A -P-curcumin }}{ }^{-}$ $\varepsilon_{A \beta}-\varepsilon_{\mathrm{P} \text {-curcumin }}$ is the extinction coefficient at $430 \mathrm{~nm}$. The binding constant can be calculated from a double-reciprocal plot $(1 /(\Delta \mathrm{A})$ against $1 /[\mathrm{A} \beta])$. As shown in Fig. $7 \mathrm{a}$, the decrease in absorbance of P-curcumin was observed upon addition of $A \beta$. Thus, based on equation (1), the $K$ value at a given condition can be obtained using the ratio of intercept and the slope, which was found to be approximately $7.66 \times 10^{4} \mathrm{M}^{-1}$. The binding constant at a specific condition did not truly reflect the real interaction with cell membrane. In the free state, the tail of the fatty acid was folded back towards the curcumin (as shown in Fig. 1a, minimum energy, data not shown). To mimic the interaction on the cellular membrane, the liposome-trapped P-curcumin was prepared based on a literature method [46]. The physical parameters of the prepared liposome were determined. The average size of P-curcumin and curcumin-trapped liposomes were $26.29 \mathrm{~nm}$ and $39.89 \mathrm{~nm}$, respectively (see online suppl. material, Fig. S6). The zeta potentials of the liposomes for P-curcumin and curcumin were $-3.87 \mathrm{mV}$ and -3.29 $\mathrm{mV}$, respectively. Next, the liposome was titrated with $\mathrm{A} \beta$ (Fig. 7b). There was a significant difference between free P-curcumin and curcumin trapped in liposomes (Fig. 7a-b). In contrast to free P-curcumin, for liposome-encased curcumin there was almost no change in absorbance at $430 \mathrm{~nm}$, but the absorbance increased in the range of 205-230 nm, which may stem from the interaction, since the contribution of $A \beta(1 \mu \mathrm{M})$ in the same range was far less than the above mentioned changes in absorbance $(<0.01$ at $215 \mathrm{~nm})$, thus the absorption changes at $215 \mathrm{~nm}$ were used for calculation (Fig. 7c), and the value of $\mathrm{K}$ was determined to be $3.71 \times 10^{5} \mathrm{M}^{-1}$. The interaction between the liposome trapped P-curcumin and A $\beta$ on the liposome was significantly decreased compared with free P-curcumin. To assess whether the changes in binding affinity occurred after the modification, we evaluated the binding affinities of curcumin in the same conditions (see online suppl. material, Fig. S7a; $7.61 \times 10^{5}$ $\mathrm{M}^{-1}$ and $1.44 \times 10^{6} \mathrm{M}^{-1}$ for curcumin and liposome-trapped curcumin, respectively, see online suppl. material, Fig. S7b). Accordingly, the association constant related to the $A \beta$ interaction with naked liposome was determined to be $1.51 \times 10^{6} \mathrm{M}^{-1}$ (see online suppl. material, Fig. S7c). The binding affinity of P-curcumin or liposome-trapped curcumin with $A \beta$ was weaker than that of curcumin (10-fold less for free and four-fold less for liposome trapped form). 

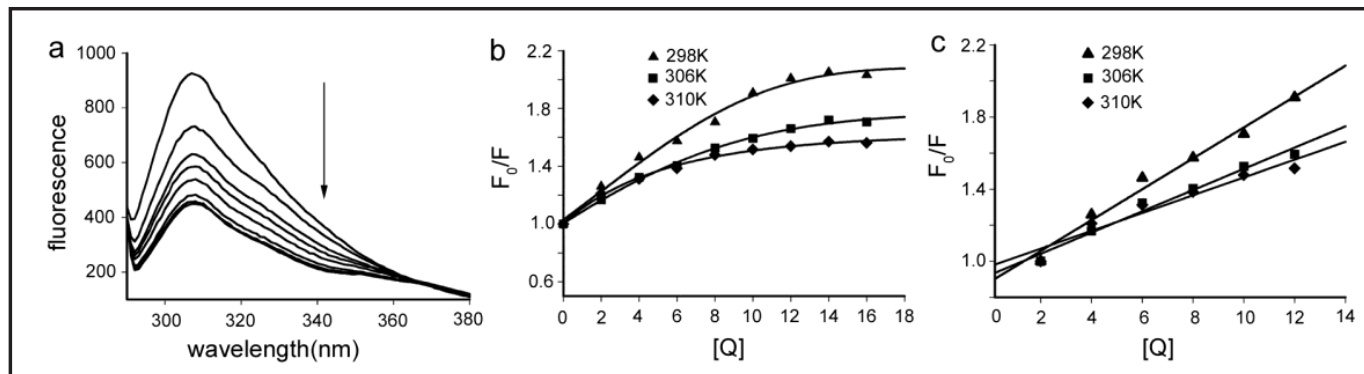

Fig. 8. Interaction of P-curcumin with $A \beta$. (a) Emission spectra of $A \beta$ in the presence of different concentrations of P-curcumin; (b) Sterm-Volmer plot for different temperatures; (c) Stern-Volmer plot for different temperature in the given range of concentration (ratio $<1.5$ ).

Analysis of interaction of P-curcumin with $A \beta$ via fluorescence spectrometry

Owing to the presence of tyrosine aromatic amino acids, $A \beta$ has intrinsic fluorescence.Thus, weused thischaracteristic to investigate the interaction of $A \beta$ with P-curcumin. Due to self-polymerization of P-curcumin (data not shown), fluorescence titration was performed in a buffer containing 10\% methanol. As shown in Fig. $8 \mathrm{a}$, the fluorescence intensity remarkably decreased as the P-curcumin concentration increased. Moreover, the emission peak did not significantly shift on A $\beta$-P-curcumin complex formation, indicating that P-curcumin could interact with $A \beta$. To obtain insights into the nature of the interactions between $A \beta$ and P-curcumin, the fluorescence quenching profile of $A \beta$ was modeled using the following Stern-Volmer equation [47].

$\mathrm{F}_{0} / \mathrm{F}=1+\mathrm{K}_{\mathrm{sv}}[\mathrm{Q})=\mathrm{K}_{\mathrm{q} \tau 0}[\mathrm{Q}](2)$

where $\mathrm{F}_{0}$ and $\mathrm{F}$ are the steady-state fluorescence intensities in the absence and presence of a quencher, respectively, [Q] is the concentration of the quencher (P-curcumin), Ksv is the Stern-Volmer dynamic quenching rate constant, $\tau_{0}$ is the fluorescence lifetime of the protein without the quencher (the average life of a fluorescence molecule is $10^{-8} \mathrm{~s} \mathrm{[46]),} \mathrm{and} \mathrm{Kq}$ is the quenching rate constant. A plot was generated of $\mathrm{F}_{0} / \mathrm{F}$ versus [Q] (Fig. 8b). The plots exhibited a nonlinear relationship at a P-curcumin- $A \beta$ molar ratio of $\leq 2: 1$, suggesting that a mixing type of quenching pattern, static and dynamic, occurred. In general, in dynamic quenching, increasing the temperature results in faster diffusion and, hence, larger amounts of collision, which increases the quenching constant, whereas in static quenching, increasing the temperature weakens the stability of the complex, reducing the quenching constant [47]. To further clarify the underlying quenching mechanism, the Stern-Volmer plots at different temperatures were generated. As shown in Fig. 8b, the curves changed as the temperature increased; however, curved lines were observed, indicating a mixing quenching model. Furthermore, we observed a linear relationship when the ratio of $\mathrm{A} \beta$ to P-curcumin was $\leq 1$ (Fig. 8c), and in the given conditions, the slope of Stern-Volmer plot decreased as the temperature increased, showing that static quenching dominated at less saturated states. When P-curcumin was in excess, the dynamic quenching also contributed to the decrease in fluorescence.

In order to understand the contribution of dynamic quenching at higher ratios of $\mathrm{P}$-curcumin to $\mathrm{A} \beta$, the quenching process was further analyzed using the following modified 


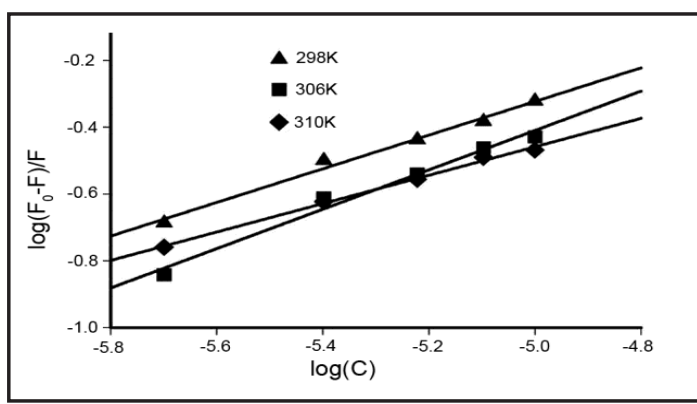

Fig. 10. Plots of $\log \left[\left(\mathrm{F}_{0}-\mathrm{F}\right) / \mathrm{F}\right]$ versus $\log [\mathrm{Q}]$ for the $\mathrm{A} \beta$ quenching effect on $\mathrm{P}$-curcumin fluorescence at different temperatures. $\mathrm{C}_{\mathrm{P} \text {-curcumin }}=1.0 \times 10^{-5} \mathrm{M} ; \mathrm{pH}$ $7.4 ; \lambda_{\mathrm{ex}}=295 \mathrm{~nm}, \lambda_{\mathrm{em}}=300-450 \mathrm{~nm}$.

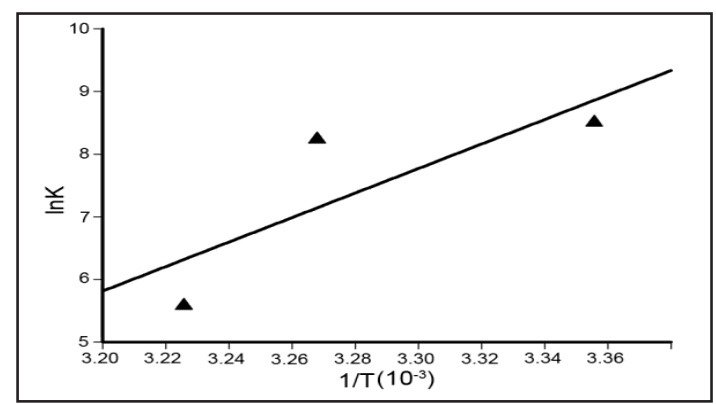

Fig. 11. Van't Hoff plot indicating the interactions between curcumin and $A \beta ; C_{P-c u r c u m i n}=1.0 \times 10^{-5} \mathrm{M}$, $\mathrm{pH} 7.4 ; \lambda_{\mathrm{ex}}=275 \mathrm{~nm}, \lambda_{\mathrm{em}}=300-450 \mathrm{~nm}$.

Stern-Volmer equation [48]:

$$
\mathrm{F}_{0} / \mathrm{F}_{0}-\mathrm{F}=\left(1 / f_{\mathrm{a}} K_{\mathrm{a}}[\mathrm{Q}]\right)+\left(1 / f_{\mathrm{a}}\right)(3)
$$

where $\mathrm{F}_{0}$ and $\mathrm{F}$ are the fluorescence intensities in the absence and presence of the quencher, respectively, $\mathrm{K}_{\mathrm{a}}$ is the effective quenching constant, which is analogous to the association binding constants in the system, $[\mathrm{Q}]$ is the concentration of the quencher, and $\mathrm{f}_{\mathrm{a}}$ is the fraction of accessible fluorescence. As shown in Fig. 9, the plots of $\mathrm{F}_{0} /\left(\mathrm{F}_{0}-\mathrm{F}\right)$ versus $[\mathrm{Q}]^{-{ }^{\mathrm{a}}}$ were linear under the investigated quencher concentrations. As the temperature increased, the slopes of the lines increased, indicating that the binding of P-curcumin to $A \beta$ decreased when the temperature increased.

\section{Binding constants and binding sites for P-curcumin}

The equilibrium process of $A \beta$ and P-curcumin could be described by Equation (4), and the association constant $\left(K_{\mathrm{b}}\right)$ and number of binding sites $(\mathrm{n})$ were calculated through using the plots [49]:

$$
\log \left(\mathrm{F}_{0}-\mathrm{F} / \mathrm{F}\right)=\log K_{\mathrm{b}}+n \log [\mathrm{Q}](4)
$$

$K_{\mathrm{b}}$ and $n$ were obtained from the intercept and slope of the curve. Thus, the plots of $\log \left[\left(\mathrm{F}_{0}-\mathrm{F}\right) / \mathrm{F}\right]$ versus $\log [\mathrm{Q}]$ were generated to determine the binding parameters (Fig. 10 ). We found that $n$ values were $0.5-0.75$; the value also showed that $K_{\mathrm{b}}$ increased as the temperature increased. This was in accordance with the aforementioned trend of $K_{\mathrm{sv}}$.

\section{Thermodynamic parameters and nature of binding forces}

The interaction of small molecules with biomacromolecules involves hydrogen bonds, electrostatic interactions, van der Waals interactions, and hydrophobic forces, which can be distinguished from thermodynamic parameters: $\Delta H>0$ and $\Delta S>0$ implied a hydrophobic interaction, $\Delta H<0$ and $\Delta S<0$ implied hydrogen bonding and van der Waals interactions, and $\Delta H<0$ and $\Delta S>0$ implied electrostatic interactions [50]. The thermodynamic parameters were obtained using the van't Hoff equation (5):

$\ln K=(-\Delta \mathrm{H} / R T)+(\Delta S / R)(5)$

where $K$ is the binding constant, $\mathrm{T}$ is the absolute temperature, and $R$ is the universal gas constant. $\Delta \mathrm{H}$ and $\Delta \mathrm{S}$ were obtained from the slope and intercept of the linear van't Hoff plot (shown in Fig. 11). The free energy change $(\Delta G)$ was estimated using the following formula:

$\Delta G=\Delta H-T \Delta S$

The values of $\Delta H, \Delta S$, and $\Delta G$ for P-curcumin binding to $\mathrm{A} \beta$ (at $298 \mathrm{~K}$ ) were determined to be $-162.69(\mathrm{~kJ} / \mathrm{mol}),-472.24(\mathrm{~J} / \mathrm{molK})$, and $-21.96(\mathrm{~kJ} / \mathrm{mol})$, respectively. Based on the views of Ross and Subramanian, a negative value for $\Delta \mathrm{H}$ and $\Delta \mathrm{S}$ implied that the interaction between P-curcumin and $A \beta$ was through hydrogen bonding and van der Waals interactions; the negative value for $\Delta G$ reveals that the interaction process was spontaneous. 


\section{Cellular Physiology Cell Physiol Biochem 2017;44:618-633

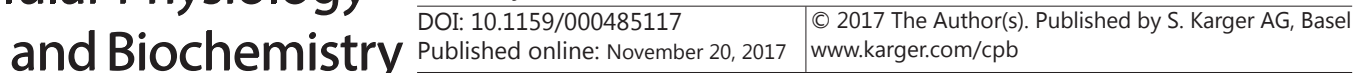

Qi et al.: Neuroblastoma Protection of Palmitic Acid Curcumin Ester

\section{Discussion}

It is a well-accepted concept in senile degenerative disease that $A \beta$ exerts cellular toxicity through oxidative stress and interaction with a cholesterol-enriched, low-density membrane domain that leads to dysfunction of nerve cells [51]. The disruption of $A \beta$ aggregation or interaction with the membrane is beneficial to patients with AD. Curcumin has been extensively studied due to its excellent antioxidant feature and radical scavenging capacity $[52,53]$. Furthermore, it has shown beneficial effects in patients with AD in East Asia [24]. Mechanistic studies have revealed that curcumin can alter $A \beta$ state during the aggregation process and dissolve oligomerized $A \beta$ [54]. Therefore, many curcumin derivatives have been synthesized to improve its therapeutic effect. Curcumin has a protective effect on neurocytes through an interaction with $A \beta$ and scavenges ROS; therefore, cultivating curcumin on cell surfaces may efficiently isolate the direct interaction of $A \beta$ and cell membrane. To test this hypothesis, we modified curcumin with a long chain fatty acid, palmitic acid, through an ester bond. The resultant P-curcumin had the capacity to attach to the cell membrane. The staining of SH-SY5Y cells clearly showed that P-curcumin was localized on the cell surface, while unmodified curcumin was uniformly distributed across the whole cell (Fig. 2). The distribution of P-curcumin on the cell membrane was not uniform; certain parts showed strong fluorescence, indicating its specific affinity to some lipid components. In the presence of $A \beta$, curcumin-enhanced fluorescence was observed in P-curcumin-treated cells; however, no significant difference was observed. We assessed the antiproliferative effect of P-curcumin against SH-SY5Y cells. A time-independent growth inhibition was observed, which has an advantage over curcumin and potent applications in AD therapy. There was no significant difference in resistance to $A \beta$ (soluble and fibrillar) insult, showing a similar protective effect (Fig. 3). It has been demonstrated that affecting cell morphology can also determine cell function, and the cell shape change due to affecting attachment had a potential effect on cell differentiation $[55,56]$. Importantly, neurocyte growth patterns may be correlated to synaptic functions [57]. The change in morphology induced by the drug may affect neurocyte growth. Thus, we investigated the effect of P-curcumin on the morphology of SH-SY5Y cells. Interestingly, P-curcumin had a much weaker effect on cell morphology than curcumin (Fig. 4) during the 24-h incubation period, which may imply a lesser effect on neuron function. However, P-curcumin can alter the components of cell membranes, leading to changes in cell fluidity $[58,59]$. The cytotoxicity of $A \beta$ was due to the generation of ROS, and, therefore, the scavenging of ROS by P-curcumin is critical. Data from in vitro and in vivo studies clearly showed that the modification did not alter its antioxidant activity (Fig. 5). We observed that in the presence of copper or ferrous ions, the generation of ROS by A $\beta$ was enhanced, which is consistent with the literature $[18,60]$. Lipid peroxidation is an ROS oxidative product, which may impair normal cell function. Thus, lipid peroxidation was further evaluated. Both curcumin and P-curcumin could decrease lipid peroxidation induced by $A \beta$, but the former decreased the peroxidation to a greater degree. This may be due to the presence of fewer phenol groups after a phenol group was used for the ester bond in P-curcumin (Fig. 6a). However, in the presence of fibrillar $A \beta, P$-curcumin is stronger than curcumin in reducing $A \beta$ cytotoxicity (Fig. 6b). In contrast, numerous studies have demonstrated that neurotoxicity is influenced by the interaction of $A \beta$ with cell membranes through the formation of annular $A \beta$ structures bound to lipid membranes or carpet-like coverings on the cell surface [61, 62]. Therefore, altering $A \beta$ aggregation or attenuating the direct interaction of $A \beta$ oligomers with cell membranes was a good option to reduce the adverse consequences of $A \beta$. We cultivated curcumin on the cell surface to isolate the direct interaction between $A \beta$ and the cell membrane. To evaluate the isolation, we determined the interaction parameters, such as the binding affinity of curcumin and P-curcumin to A $\beta$. Spectral techniques are widely used to determine the interactions between biomacromolecules and ligands. Thus, based on spectral methods, the binding affinity of P-curcumin in the free state with $A \beta$ was determined to be approximately $7.66 \times 10^{4} \mathrm{M}^{-1}$. Accordingly, the binding affinity of curcumin at the same condition was also evaluated for comparison $\left(7.61 \times 10^{5} \mathrm{M}^{-1}\right)$. It was clearly weaker in affinity 
after the modification, which could have been caused by the attenuation of the interaction between $A \beta$ and curcumin due to disruption of the fatty chain. To mimic the interaction of $A \beta$ with the membrane, cholesterol-enriched liposomes and liposome-trapped P-curcumin were prepared. In the given condition, the binding constants for P-curcumin and curcumin were found to be $3.71 \times 10^{5}$ and $1.44 \times 10^{6} \mathrm{M}^{-1}$, respectively. The binding affinities were different in free and liposome-trapped states. This may be because in the trapped form, the fatty chain (P-curcumin) can be extended to liposomes through hydrophobic interactions, while the head (curcumin) could be fully or partly protruded out of the surface of the liposome. The differences in binding affinity (free and liposome) may reflect the difference in conformation of P-curcumin. On the other hand, the difference between curcumin and P-curcumin in binding affinities to liposomes may also reflect the difference in the state of curcumin in the liposome. Curcumin trapped in liposomes may be fully buried, due to which $A \beta$ interacts directly with the surface of the liposome. However, in the case of P-curcumin-trapped liposomes, the proportion of $A \beta$ interactions with the surface of the liposome was lower than that in curcumin-trapped liposomes. The association constant for P-curcumin-trapped liposomes was almost the same as that for curcumin-trapped liposome, which supports the above speculation. The interaction between $A \beta$ and lipid vesicles can be modulated by surface charge and hydrophobicity of the membranes, and $A \beta$ preferentially binds to negatively charged phosphatidylglycerol membranes and composite membranes containing negatively charged lipids compared with neutrally charged membranes [8]. Therefore, the difference in binding affinity between $A \beta$ and liposomes was also indicative of the above-mentioned factors in the present study. However, to obtain more insights into the consequence of the modification, the effects of P-curcumin on membrane fluidity, ion channel, and receptors on membrane need to be extensively explored in future.

\section{Conclusion}

Placing curcumin on cell membrane surfaces by modifying curcumin with a fatty acid chain to isolate the direct $A \beta$ interaction with the membrane was investigated. Data showed that the modification did not alter the antioxidant activity and ROS scavenging ability of curcumin. The beneficial aspect after the structural modification was the attenuating effect of curcumin on neurocyte morphology, which may be beneficial in neuron communication in patients with $\mathrm{AD}$. The difference in association constants between liposome-trapped curcumin and P-curcumin also suggested that the cultivated curcumin could partly inhibit the direct interaction between $A \beta$ and membrane, which may efficiently reduce the neurocyte damage induced by $A \beta$. This could find potential applications in the prevention and therapy of AD. However, the effects of P-curcumin on the membrane fluidity of neurocytes, neurocyte outgrowth, ion channel, and receptors on membrane need to be studied in detail.

\section{Acknowledgements}

This study was supported through grants awarded by the Natural Science Foundation of China (No. 21571153), undergraduate innovation project of Xinxiang Medical University for Zhangyang Qi, and Bureau of Science and Technology of Xinxiang (ZG12027 and CXGG16019).

\section{Disclosure Statement}

The authors declare that there are no competing financial interests or any other potential Disclosure Statement. 


\section{Cellular Physiology Cell Physiol Biochem 2017;44:618-633 \begin{tabular}{l|l} 
and Biochemistry Published 10.1159/000485117 & $\begin{array}{l}\text { (c) 2017 The Author(s). Published by S. Karger AG, Basel } \\
\text { www.karger.com/cpb }\end{array}$
\end{tabular} \\ Qi et al.: Neuroblastoma Protection of Palmitic Acid Curcumin Ester}

\section{References}

-1 Ferri CP, Prince M, Brayne C, Brodaty H, Fratiglioni L, Ganguli M, Hall K, Hasegawa K, Hendrie H, Huang Y, Jorm A, Mathers C, Menezes PR, Rimmer E, Scazufca M: Global prevalence of dementia: a Delphi consensus study. Lancet 2005;366:2112-2117.

-2 Hardy J, Selkoe DJ: The amyloid hypothesis of Alzheimer's disease: progress and problems on the road to therapeutics. Science 2002;297:353-356.

3 Pratico D: Oxidative stress hypothesis in Alzheimer's disease: a reappraisal. Trends Pharmacol Sci 2008;29:609-615.

4 Haass C, Hung AY, Schlossmacher MG, Oltersdorf T, Teplow DB, Selkoe DJ: Normal cellular processing of the betaamyloid precursor protein results in the secretion of the amyloid beta peptide and related molecules. Ann NY Acad Sci 1993;695:109-116.

5 Selkoe DJ: Soluble oligomers of the amyloid beta-protein impair synaptic plasticity and behavior. Behav Brain Res 2008;192:106-113.

6 Lenhart JA, Ling X, Gandhi R, Guo TL, Gerk PM, Brunzell DH, Zhang SJ: “Clicked” bivalent ligands containing curcumin and cholesterol as multifunctional $A \beta$ oligomerization inhibitors: Design, synthesis, and biological characterization. J Med Chem 2010;53:6198-6209.

-7 Vetrivel KS, Thinakaran G: Amyloidogenic processing of $\beta$-amyloid precursor protein in intracellular compartments. Neurology 2006;66:S69-S73.

$>8$ Williams TL, Serpell LC: Membrane and surface interactions of Alzheimer's A $\beta$ peptide--insights into the mechanism of cytotoxicity. FEBS J 2011;278:3905-3917.

-9 Chávez-Gutiérrez L, Bammens L, Benilova I, Vandersteen A, Benurwar M, Borgers M, Lismont S, Zhou L, Van Cleynenbreugel S, Esselmann H, Wiltfang J, Serneels L, Karran E, Gijsen H, Schymkowitz J, Rousseau F, Broersen K, De Strooper B: The mechanism of $\gamma$-Secretase dysfunction in familial Alzheimer disease. EMBO J 2012;31:2261-2274.

10 Goate A, Chartier-Harlin MC, Mullan M, Crawford F, Fidani L, Giuffra L, Haynes A, Irving N, James L et al: Segregation of a missense mutation in the amyloid precursor protein gene with familial Alzheimer's disease. Nature 1991;349:704-706.

-11 Carrillo-Mora P, Luna Rogelio, Colín-Barenque L: Amyloid Beta: Multiple mechanisms of toxicity and only some protective effects?. Oxid Med Cell Longev 2014;2014:795375.

-12 Ritchie CW, Bush AI, Mackinnon A, Macfarlane S, Mastwyk M, MacGregor L, Kiers L, Cherny R, Li QX, Tammer A, Carrington D, Mavros C, Volitakis I, Xilinas M, Ames D, Davis S, Beyreuther K, Tanzi RE, Masters CL: Metal-protein attenuation with iodochlorhydroxyquin (clioquinol) targeting Abeta amyloid deposition and toxicity in Alzheimer disease: a pilot phase 2 clinical trial. Arch Neurol 2003;60:1685-1691.

13 Mishra P, Ayyannan SR, Panda G: Perspectives on inhibiting $\beta$-amyloid aggregation through structure-based drug design. Chem Med Chem 2015;10:1467-1474.

14 Habchi J, Arosio P, Perni M, Costa AR, Yagi-Utsumi M, Joshi P, Chia S, Cohen SIA, Müller MBD, Linse S, Nollen EAA, Dobson CM, Knowles TPJ, Vendruscolo M: An anticancer drug suppresses the primary nucleation reaction that initiates the production of the toxic A $\beta 42$ aggregates linked with Alzheimer's disease. Sci Adv 2016;2:e1501244.

15 Verdier Y, Zarándi M, Penke B: Amyloid beta-peptide interactions with neuronal and glial cell plasma membrane: binding sites and implications for Alzheimer's disease. J Pept Sci 2004;10:229-248.

16 Petersen RB, Nunomura A, Lee H G, Casadesus G, Perry G, Smith MA, Zhu X: Signal transduction cascades associated with oxidative stress in Alzheimer's disease. J Alzheimer's Dis 2007;11:143-152.

17 Reddy PH, Beal MF: Amyloid $\beta$, mitochondrial dysfunction and synaptic damage: implications for cognitive decline in aging and Alzheimer's disease. Trends Mol Med 2008;14:45-53.

-18 Méndez-Garrido A, Hernández-Rodríguez M, Zamorano-Ulloa R, Correa-Basurto J, Mendieta-Wejebe JE, Ramírez-Rosales D, Rosales-Hernández MC: In vitro effect of $\mathrm{H}_{2} \mathrm{O}_{2}$, some transition metals and hydroxyl radical produced via fenton and fenton-like reactions, on the catalytic activity of AChE and the hydrolysis of ACh. Neurochem Res 2014;39:2093-2104.

-19 Butterfield DA, Reed T, Newman SF, Sultana R: Roles of amyloid $\beta$-peptide-associated oxidative stress and brain protein modifications in the pathogenesis of Alzheimer's disease and mild cognitive impairment. Free Radical Biol Med 2007;43:658-677.

20 Lin H, Bhatia R, Lal R: Amyloid $\beta$ protein forms ion channels: implications for Alzheimer's disease pathophysiology. FASEB J 2001;15:2433-2444. 


\section{Cellular Physiology Cell Physiol Biochem 2017;44:618-633 \begin{tabular}{ll|l} 
DOI: 10.1159/000485117 & O 2017 The Author(s). Published by S. Karger AG, Basel \\
www.karger.com/cpb
\end{tabular}

-21 Rosales-Corral S, Tan DX, Reiter RJ, Valdivia-Vel'azquez M, Acosta-Mart'inez JP, Ortiz GG: Kinetics of the neuroinflammation-oxidative stress correlation in rat brain following the injection of fibrillar amyloid- $\beta$ onto the hippocampus in vivo. J Neuroimmunol 2004;150:20-28.

-22 Feng Y, Wang X: Antioxidant therapies for Alzheimer's disease. Oxid Med Cell Longev 2012;2012:472932.

-23 Dumont M, Beal MF: Neuroprotective strategies involving ROS in Alzheimer disease. Free Radical Biol Med 2011;51:1014-1026.

24 Ng TP, Chiam PC, Lee T, Chua HC, Lim L, Kua, EH: Curry consumption and cognitive function in the elderly. Am J Epidemiol 2006;164:898-906.

-25 Gupta SC, Patchva S, Aggarwal BB: Therapeutic roles of curcumin: lessons learned from clinical trials. AAPS J 2013;15:195-218.

26 Morabito R, Falliti G, Geraci A, Spada GL, Marino A. Curcumin protects -SH groups and sulphate transport after oxidative damage in human erythrocytes. Cell Physiol Biochem 2015;36:345-57.

27 Maheshwari RK, Singh AK, Gaddipati J, Srimal RC: Multiple biological activities of curcumin: a short review. Life Sci 2006;78:2081-2087.

28 Yang W, Fu J, Yu M, Wang D, Rong Y, Yao P, Nüssler AK, Yan H, Liu L. Effects of three kinds of curcuminoids on anti-oxidative system and membrane deformation of human peripheral blood erythrocytes in high glucose levels. Cell Physiol Biochem 2015;35:789-802.

$\checkmark 29$ Oliveira AS, Sousa E, Vasconcelos MH, Pinto M: Curcumin: A natural lead for potential new drug candidates. Curr Med Chem 2015;22:1-37.

30 Yang F, Lim GP, Begum AN, Ubeda OJ, Simmons MR, Ambegaokar SS, Chen PP, Kayed R, Glabe CG, Frautschy SA, Cole GM: Curcumin inhibits formation of amyloid beta oligomers and fibrils, binds plaques, and reduces amyloid in vivo. J Biol Chem 2005;280:5892-5901.

-31 Moss MA, Varvel NH, Nichols MR, Reed DK, Rosenberry TL: Nordihydroguaiaretic acid does not disaggregate beta-amyloid(1-40) protofibrils but does inhibit growth arising from direct protofibril association. Mol Pharmacol 2004;66:592-600.

-32 Reinke AA, Gestwicki JE: Structure-activity relationships of amyloid beta aggregation inhibitors based on curcumin: influence of linker length and flexibility. Chem Biol Drug Des 2007;70:206-215.

-33 Park SY, Kim HS, Cho EK, Kwon BY, Phark S, Hwang KW, Sul D: Curcumin protected PC12 cells against betaamyloid-induced toxicity through the inhibition of oxidative damage and tau hyperphosphorylation. Food Chem Toxicol 2008;46:2881-2887.

-34 Ma QL, Zuo X, Yang F, Ubeda OJ, Gant DJ, Alaverdyan M, Teng E, Hu S, Chen PP, Maiti P, Teter B, Cole GM, Frautschy SA: Curcumin suppresses soluble tau dimers and corrects molecular chaperone, synaptic, and behavioral deficits in aged human tau transgenic mice. J Biol Chem 2013;288:4056-4065.

-35 Zhang L, Fiala M, Cashman J, Sayre J, Espinosa A, Mahanian M, Zaghi J, Badmaev V, Graves MC, Bernard G, Rosenthal M: Curcuminoids enhance amyloid-beta uptake by macrophages of Alzheimer's disease patients. J Alzheimers Dis 2006;10:1-7.

>36 Koronyo-Hamaoui M, Koronyo Y, Ljubimov AV, Miller CA, Ko MK, Black KL, Schwartz M, Farkas DL: Identification of amyloid plaques in retinas from Alzheimer's patients and noninvasive in vivo optical imaging of retinal plaques in a mouse model. Neuroimage 2011;54:S204-217.

37 Goozee KG, Shah TM, Sohrabi HR, Rainey-Smith SR, Brown B, Verdile G, Martins RN: Examining the potential clinical value of curcumin in the prevention and diagnosis of Alzheimer's disease. Br J Nutr 2016;115:449-465.

38 Yanagisawa D, Taguchi H, Yamamoto A, Shirai N, Hirao K, Tooyama I: Curcuminoid binds to amyloid- $\beta 1-42$ oligomer and fibril. J Alzheimers Dis 2011;2:33-42.

-39 Demuro A, Mina E, Kayed R, Milton SC, Parker I, Glabe CG: Calcium dysregulation and membrane disruption as a ubiquitous neurotoxic mechanism of soluble amyloid oligomers. J Biol Chem 2005;280:17294-17300.

40 Huang TF, Li CP, Sun XZ, Zhu ZF, Yun F, Liu YX, Yuan YB, Li SS, Li CZ: The antitumor mechanism of di2-pyridylketone 2-pyridine carboxylic acid hydrazone and its copper complex in ROS generation and topoisomerase inhibition, and hydrazone involvement in oxygen-catalytic iron mobilization. Int J Oncol 2015;47:1854-1862.

41 Gasparovic AC, Jaganjac M, Mihaljevic B, Sunjic SB, Zarkovic N: Assays for the measurement of lipid peroxidation. Methods Mol Biol 2013;965:283-296.

42 Thapa A, Jett SD, Chi EY: Curcumin attenuates amyloid- $\beta$ aggregate toxicity and modulates amyloid- $\beta$ aggregation pathway. ACS Chem Neurosci 2016;7:56-68. 


\section{Cellular Physiology Cell Physiol Biochem 2017;44:618-633

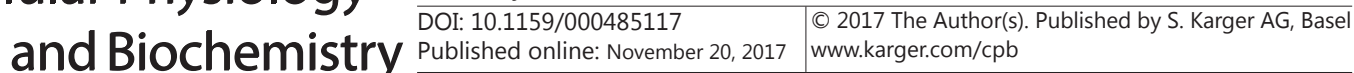

43 Huang HC, Chang P, Lu SY, Zheng BW, Jiang ZF: Protection of curcumin against amyloid- $\beta$-induced cell damage and death involves the prevention from NMDA receptor-mediated intracellular $\mathrm{Ca}^{2+}$ elevation. J Recept Signal Transduct Res 2015;35:450-457.

44 Smith DG, Cappai R, Barnham KJ: The redox chemistry of the Alzheimer's disease amyloid beta peptide. Biochim Biophys Acta 2007;1768:1976-1990.

45 Kuntz Jr ID, Gasparro FP, Johnston Jr MD, Taylor RP: Molecular interactions and the Benesi-Hildebrand equation. J Am Chem Soc 1968;90:4778-4781.

46 Mutalik S, Salian SR, Avadhani K, Menon J, Joshi H, Hegde AR, Kumar P, Kalthur G, Adiga SK: Liposome encapsulated soy lecithin and cholesterol can efficiently replace chicken egg yolk in human semen cryopreservation medium. Syst Biol Reprod Med 2014;60:183-188.

47 Xu HL, Yao NN, Xu HR, Wang TS, Li GY, Li ZQ: Characterization of the interaction between eupatorin and bovine serum albumin by spectroscopic and molecular modeling methods. Int J Mol Sci 2013;14:1418514203.

-48 Bijari N, Shokoohini Y, Ashrafi-Kooshk MR, Ranjbara S, Parvaneh S, Moieni-Arya M, Khodarahmi R: Spectroscopic study of interaction between osthole and human serum albumin: Identification of possible binding site of the compound. J Lumin 2013;143:328-336.

-49 Li CP, Huang TF, Fu Y, Liu YX, Zhou SF, Qi ZY, Li CZ: Interaction of Di-2-pyridylketone 2-pyridinecarboxylic acid hydrazone and its copper complex with BSA: Effect on antitumor activity as revealed by spectroscopic studies. Molecules 2016;21:563.

50 Timaseff SN. Thermodynamics of Protein Interactions. Peeters H (eds): In Proteins of Biological Fluids. Pergamon Press, Oxford, UK, 1972;pp511-519.

51 Joshi P, Chia S, Habchi J, Knowles TPJ, Dobson CM, Vendruscolo M: A fragment-based method of creating small-molecule libraries to target the aggregation of intrinsically disordered proteins. ACS Comb Sci 2016;18:144-153.

52 Gibson Wood W, Eckert GP, Igbavboa U, Müller WE: Amyloid beta-protein interactions with membranes and cholesterol: causes or casualties of Alzheimer's disease. Biochim Biophys Acta 2003;1610:281-290.

>53 Zheng L, Li Y, Li X, Kou J, Zhong Z, Jiang Y, Liu Z, Tian Y, Yang L: Combination of hydroxyl acetylated curcumin and ultrasound induces macrophage autophagy with anti-apoptotic and anti-lipid aggregation effects. Cell Physiol Biochem 2016;39:1746-1760.

54 Ak T, Gülçin I: Antioxidant and radical scavenging properties of curcumin. Chem BiolInteract 2008;174:2737.

55 Yang F, Lim GP, Begum AN, Ubeda OJ, Simmons MR, Ambegaokar SS, Chen PP, Kayed R, Glabe CG, Frautschy SA, Cole GM: Curcumin inhibits formation of amyloid beta oligomers and fibrils, binds plaques, and reduces amyloid in vivo. J Biol Chem 2005;280:5892-5901.

-56 Aw Yong KM, Zeng Y, Vindivich D, Phillip JM, Wu PH, Wirtz D, Getzenberg RH: Morphological effects on expression of growth differentiation factor 15 (GDF15), a marker of metastasis. J Cell Physiol 2014;229:362-373.

-57 Zare-Mehrjardi N, Khorasani MT, Hemmesi K, Mirzadeh H, Azizi H, Sadatnia B, Hatami M, Kiani S, Barzin J, Baharvand H: Differentiation of embryonic stem cells into neural cells on 3D poly (D, L-lactic acid) scaffolds versus 2D cultures. Int J Artif Organs 2011;34:1012-1023.

58 Reese D, Drapeau P: Neurite growth patterns leading to functional synapses in an identified embryonic neuron. J Neurosci 1998;18:5652-5662.

59 Yang X, Sheng W, Sun GY, Lee JC: Effects of fatty acid unsaturation numbers on membrane fluidity and $\alpha$-secretase-dependent amyloid precursor protein processing. Neuro Chem Int 2011;58:321-329.

60 Ibarguren M, López DJ, Escribá PV: The effect of natural and synthetic fatty acids on membrane structure, microdomain organization, cellular functions and human health. Biochim Biophys Acta 2014;1838:15181528.

61 Cassagnes LE, Hervé V, Nepveu F, Hureau C, Faller P, Collin F: The catalytically active copper-amyloid-beta state: coordination site responsible for reactive oxygen species production. Angew Chem Int Ed Engl 2013;52:11110-11113.

62 Hertel C, Terzi E, Hauser N, Jakob-Rotne R, Seelig J, Kemp JA: Inhibition of the electrostatic interaction between beta-amyloid peptide and membranes prevents beta-amyloid-induced toxicity. Proc Natl Acad Sci USA 1997;94:9412-9416. 